\title{
Viewpoint: Plant community thresholds, multi- ple steady states, and multiple successional pathways: legacy of the Quaternary?
}

\author{
ROBIN J. TAUSCH, PETER E. WIGAND, AND J. WAYNE BURKHARDT
}

Authors are project leader, U.S. Department of Agriculture, Forest Service, Intermountain Research Station, Reno, Nev. 89512; associate research professor, Desert Reserch Institute, University of Nevada System, Reno 89506; and associate professor, Department of Range, Wildlife, and Forestry, University of Nevada, Reno 89512.

\begin{abstract}
The climate cycles of the 2 million years of the Quaternary were a major force in the evolution of plant response to change. Quaternary climate has been primarily glacial with interglacials such as the current Holocene a minor component. Plant species responded individually to climate changes and, consequently, species composition has continually changed. The legacy of Quaternary climate change is that plant communities are far less stable than they appear to be from our perspective. They are unique at each location, difficult to define, and communities that are relics from a previous environment can be sensitive to small or transient environmental changes. Plant communities are variable both in space and time. Many ecological principles and concepts, and ecosystem pardigms derived from them, require revision to incorporate this variation. The concepts of habitat type and condition and trend, for example, do not reflect dynamic vegetation response to changes in climate. Our knowledge is presently insufficient to adequately
\end{abstract}

\footnotetext{
Authors wish to thank Bill Laycock, Neil West, and the anonymous reviewers for their comments on the manuscript.

Manuscript accepted 13 Mar. 1993.
}

describe interactions between ecosystems and changing climate, but the patterns of vegetation response to environmental changes of the past may provide important information on vegetation response to present and future climate change. The concepts of thresholds, multiple steady states, and multiple successional pathways are helpful in understanding the dynamic interrelationships between vegetation and environmental changes.

Key Words: paleoecology, paleoclimate, thresholds, successional pathways, vegetation dynamics, environmental changes, competition, climate changes, global change, ecosystem theory, climax, condition and trend

Ecological theory that has been the basis of vegetation management for most of this century is now being questioned (Johnson and Mayeux 1992). This reevaluation has followed the accumulation of contrary information (Scholes 1990). Some basic ecological principles on which the concepts of vegetation dynamics have been based generally have not been supported by rigorous testing (Jorgensen 1990, Archer and Smeins 1992). Accumulating evidence indicates that vegetation does not respond as expected to management based on traditional concepts (Westoby et al. 1989a, 1989b; 
Botkin 1990, Johnson and Mayeux 1992, Box 1992).

All the concepts used in range management are based on models of ecosystem function (Westoby et al. 1989a, 1989b). Alternate models of vegetation dynamics include the concepts of thresholds (Friedel 1991) and multiple stable states of differing species composition with multiple, nonlinear pathways between them (Laycock 1991). As commonly applied, the concepts of habitat type and condition and trend may be incompatible with these new proposals (Friedel 1991, Laycock 1991, Svejcar and Brown 1991).

Effective modification of our approaches to management will require better understanding of the long-term processes forcing observed vegetation changes. This requires study over expanded periods of time (Foster et al. 1990, Schoonmaker and Foster 1991). It is over the longer time scales of decades to centuries that the crucial nature of our responsibilities for resource management become most evident. Without the historical perspective of longterm information, serious misjudgments in resource management can result (Magnusen 1990).

The timescale at which we observe change usually does not match the timescale at which it occurs (Scholes 1990). This difference causes problems recognizing and estimating the magnitude of changes occurring over decades or longer time scales. Vegetation responses can develop at a snail's pace relative to our sense of time. Time lags, common in ecological systems, can conceal evidence of mismanagement and the links between cause and effect, confusing our interpretation (Scholes 1990). Without long-term awareness, relationships between cause and effect can be hidden within what Magnuson (1990) calls the "invisible present".

Recent advances in paleoclimatology and paleoecology, ongoing climate change research (Walker 1982, Barbour and Billings 1988, Huntley 1991, Prentice et al. 1991), and reconstruction of vegetation history (Betancourt et al. 1990, Bryant and Holloway 1985) are effectively extending our perspective back in time. This expanded perspective is providing clues for understanding relationships between long-term climate change, with its many different physical and biological components and vegetation dynamics (Magnuson 1990). The potential effects of this climatic variation for the last century have been discussed by Neilson $(1986,1987)$ and Svejcar and Brown (1991). Paleovegetation data show that an important contributor to current vegetation dynamics has been the climatic variation of the Quaternary (the last 2 million years) as described by Schoonmaker and Foster (1991), Sprugel (1991), and others.

\section{Quaternary Climatic Patterns}

Understanding the potential importance of Quaternary climate to observed vegetation dynamics also requires an understanding of how the Quaternary differed from the preceding Tertiary period ( 2 to 65 million years B.P.). Data from the Miocene and Pliocene Epochs at the end of the Tertiary (2 to 20 millions years B.P.) suggest communities were more complex, reflecting a warmer, more humid, and relatively stable climate compared to the Quaternary (Nilsson 1982, Gould 1991, Morrison 1991a, Schoonmaker and Foster 1991, Thompson 1991). Many Pliocene species apparently had relatively narrow ranges of tolerance of adaptability to environmental variation (Bradshaw and McNeilly 1991) and disappeared during the glacial cycles of the Quaternary.

A relatively detailed picture of Quaternary climate variation has become available from terrestrial and deep sea floor cores, ice cores, and deep ground water spring deposits during recent years (Adam 1988; Webb 1986, 1991; Eddy and Bradley 1991; Winograd et al. 1992). Over the 2 million years of the Quaternary, these data indicate considerable and continuous climatic variation (Mitchell 1976, Smiley et al. 1991). Up to 24 glacial events of about $50-100,000$ years each have occurred (van Donk 1976). The longer

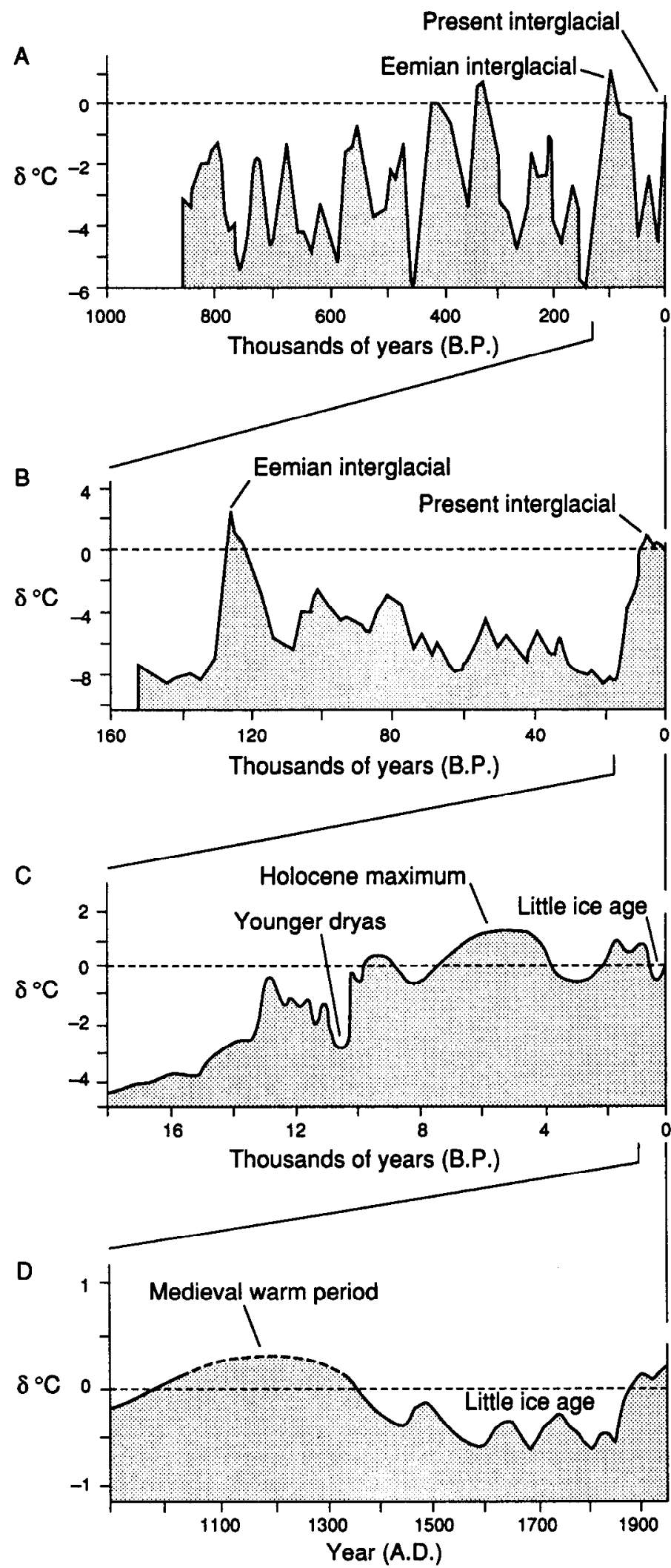

Fig. 1. Reconstructions of the history of surface temperature deviations $\left({ }^{\circ} \mathrm{C}\right)$ for the last 850,000 years $(1 \mathrm{~A})$, the last 150,000 years $(1 \mathrm{~B})$, the last 18,000 years $(1 C)$, and the last 1,000 years (1D). Mean annual temperature deviations are from the mean value of the present century of about $15^{\circ} \mathrm{C}$. Figures are adapted from Eddy and Bradley (1991). 
glacial events dominated the last 700,000 years (Schoonmaker and Foster 1991). Glacial periods have been interspersed with much shorter warm interglacials ranging from 10-20,000 years. Variations in average annual global temperature have exceeded $6^{\circ} \mathrm{C}$ (Fig. 1A) over these glacial and interglacial cycles.

Over the last 850,000 years average global temperatures were mostly well below that of the present. Periods with global temperatures equivalent to today's occurred only infrequently, were of short duration, and comprised, at current estimates, roughly $10 \%$ of the period (Fig. 1A). Some past climatic regimes apparently have no modern analogs (Schoonmaker and Foster 1991), and seasonal temperature and precipitation patterns have changed independently in complex interactions (Prentice et al. 1991). Local patterns varied due to mountain uplift and changing oceanic circulation patterns.

The prevailing global climate of the last 150,000 years (Fig. 1B) was also glacial (Schoonmaker and Foster 1991). Periods when temperatures were equivalent to those of today represent a minor part of the total. Events such as the last interglacial, the Eemian (Sangammon), and our current Holocene interglacial can be viewed on geological timescales as periods of drought in the otherwise prevailing glacial climate.

Spatially and temporally variable climates probably have been an important force in plant evolution for 2 million years. The result has been oscillations in geographic isolation, genetic composition, founder effects, and the continuous development of new plant genotypes (Webb 1987, McArthur et al. 1988, Huntley and Webb 1989). Interglacial periods have probably been too infrequent, too short, and too divergent from the general trend for significant evolution to occur compared to the prevailing glacial climate (Bennett 1990, Gould 1991). Schoonmaker and Foster (1991) describe interglacials as times of stress when the biotic cards were reshuffled. It is possible that genetic differences developed during glacial, as opposed to interglacial, periods coexist in present populations (Ogden 1989).

However, interglacials have been long enough, and extreme enough, to cause extinction (Jablonski 1991, Schoonmaker and Foster 1991). For example, many species of mega-fauna in the Western Hemisphere were lost by 10,000 to 11,000 years ago (Kurten and Anderson 1980, Grayson 1991, Lewin 1987, OwenSmith 1987, Gould 1991). Climatic warming and drought at the beginning of the Holocene interglacial, the associated loss of Pleistocene plant communities, and hunting associated with human arrival in the region all possibly contributed to the loss (Geist 1989).

Toward the end of the Pleistocene (between 13,000 and 14,000 years ago) temperatures began rapidly increasing, reaching the Holocene maximum between 5,000 to 7,000 years ago (Fig. 1C). Changes in the species composition of southwestern plant communities during this period included the migration of singleleaf pinyon (Pinus monophylla Torr. and Frem.) into the Great Basin (Thompson 1990) and creosotebush [Larrea tridentata (Ses. \& Moc. Ex. DC.)//cov.] into the Chihuahuan, Sonoran, and Mojave Deserts (Johnson and Mayeux 1992). During the warmest part of the Holocene, Lake Tahoe was as much as $12 \mathrm{~m}$ below its current level. Tree trunks rooted below the current lake level have been carbon dated to the period (Davis et al. 1976, Lindstrom 1990 , Furgurson and Mobley 1992). The onset of the Medieval Warm Period (Fig. 1D) coincides with an increased fire frequency in the western United States (Sprugel 1991).

The last several hundred years have been dominated by the Little Ice Age (Fig. 1D) which ended in the late 1800's (Wahl and Lawson 1970). The warming trend of the last century, and associated shifts in seasonal patterns and amounts of rainfall, coincided with a rapid expansion of woody plant species into southwestern perennial grassland communities (Neilson 1986, 1987) and Texas savannahs (Archer 1989), and an increased tree dominance in pine forests (Savage 1991). The widespread introduction of livestock grazing at the same time probably played an important role in the expansion. Woody plant invasions, however, also occurred in areas not subject to grazing, possibly due in part to a concomitant reduction in fire frequency (Burkhardt Tisdale 1976).

Evidence needed to understand the potential effect of 2 million years of variable climate on plant species and community dynamics can be inferred from pollen studies covering up to 1.6 million years for coastal California (Heusser and King 1988) and 120,000 years at Clear Lake, California (Adam 1985). Pacific Northwest studies provide a record exceeding 65,000 years (Heusser 1985). Data from pollen studies from other areas (Turekian 1971; Bryant and Holloway 1985; Berglund 1986; Webb 1987; Schoonmaker and Foster 1989,1990 ) show similar variations. Woodrat midden studies (Betancourt et al. 1990, Nowak 1991, Wigand and Nowak 1992) show greater detail for the changes in the species composition of southwestern United States plant communities for over 45,000 years (Webb and Bettancourt 1990). Ecologically dynamic communities with substantial variation in species combinations evident over the last 100,000 years have probably been characteristic of the entire Quaternary (Webb 1987, Schoonmaker and Foster 1991).

The record for a midden in western Nevada (Nowak 1991, Wigand and Nowak 1992) provides additional western Great Basin examples of these variations. Some high elevations species present prior to the glacial maximum are no longer present locally. Some xeric species present today were not present in the past. Other species were present before and after, but not during the last glacial maximum. Many species, however, were present throughout the period. One species, Utah juniper (Juniperus osteosperma [Torr.] Little), is present in every sampled stratum of the 30,000 year record of this midden.

Other data from this midden (Nowak 1991, Wigand and Nowak 1992) show that at 23,000 years ago and again at 12,000 years ago Utah juniper and whitebark ( Pinus albicaulis Engelm.) co-occurred at about $1,400 \mathrm{~m}$ in elevation on the west side of Pyramid Lake (Fig. 2). Curlleaf mahogany (Cercocarpus ledifolius [Nutt.] T\&G was also present in the 12,000 year old stratum. Although still present in the same area, curlleaf mahogany now occurs nearly $1,000 \mathrm{~m}$ higher and over $50 \mathrm{~m}$ above the current highest elevation stands of juniper. Whitebark pine no longer occurs in the mountains west of Pyramid Lake. The nearest locations are $50 \mathrm{~km}$ and more southwest of the midden site on Peavine Mountain and the Carson Range. The juniper nearest to present locations of whitebark pine is $11 \mathrm{~km}$ away and about $1,100 \mathrm{~m}$ lower in elevation. Similar changes have been documented for other species and locations (Webb 1987, Betancourt et al. 1990).

Fluctuations in the level of pluvial Lake Lahontan from the last 35,000 years (Fig. 3) are more detailed, but similar to those for the last 1 million years for both Lakes Lahontan and Bonneville (Morrison 1991b) and 2 million years for Searles Lake, California (Smiley et al. 1991). These records provide additional data on past climatic variations for this region. Lake levels were determined primarily from dating of calcareous tufa deposited on rocks while they were submerged in the pluvial lake, and from topographic and sedimentary evidence (Thompson et al. 1986, Benson and Thompson 1987, Benson et al. 1990, Benson 1991, Morrison 1991b). The simultaneous occurrence of juniper, curlleaf mahogany, and whitebark pine in a single middle stratum also coincides with the highest proposed lake level (Fig. 3) and both plants and lake level reflect increased effective precipitation. Neither curlleaf mahogany nor whitebark pine were found in strata from the same midden (Nowak 1991, Wigan and Nowak 1992) dated after the demise of the pluval lake. Juniper's persistence over 30,000 years in western 


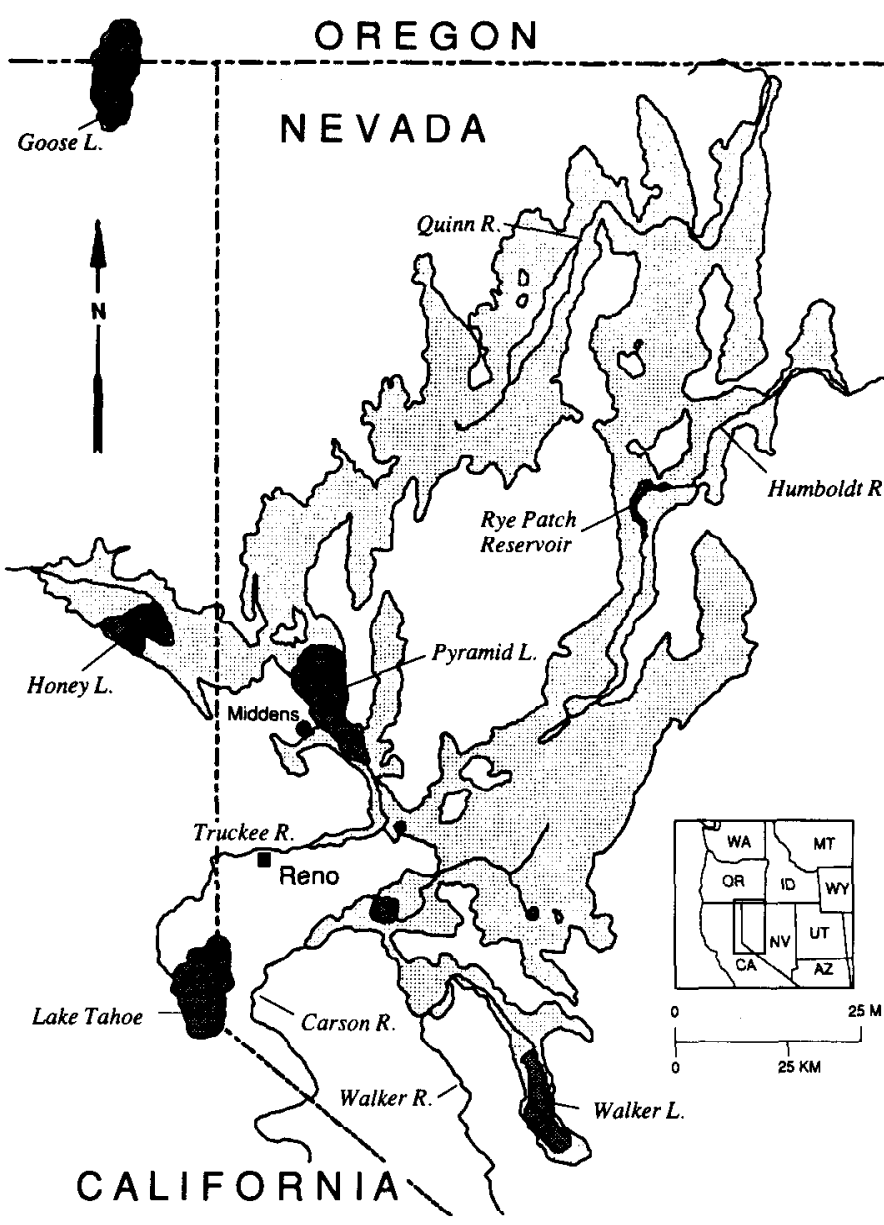

Fig. 2. Location of middens discussed in the text in relationship to the extent of Pluvial Lake Lahontan at its last high stand, 13,000 to 14,000 years B.P. Lake level data for Pluvial Lake Lahontan are from Benson et al. (1990) and Benson (1991).

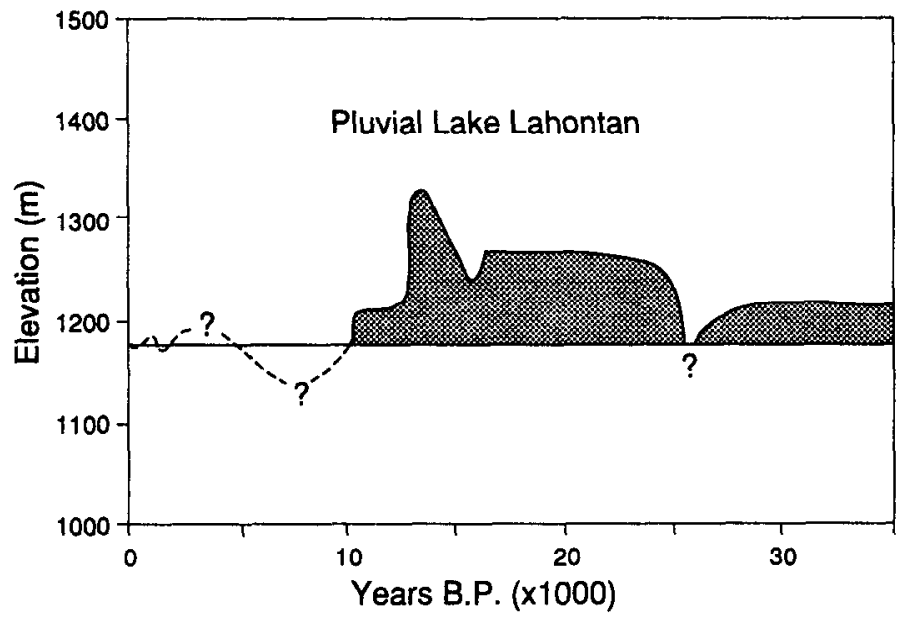

Fig. 3. Reconstructed Pluvial Lake Lahontan levels for the past 35,000 years. Redrawn from Thompson et al. (1986), Benson and Thompson (1987), Benson et al. (1990), and Benson (1991).

Nevada (Nowak 1991, Wigand and Nowak 1992) despite considerable migration by other species indicates juniper has a high level of tolerance or adaptability to climate change.

Vegetation change has occurred coincidently on a global scale; for example, in eastern North America (Jacobsen et al. 1987,
Jackson and Whitehead 1991), in Europe (Iverson 1973), in the near and middle East (Brice 1978), and in tropical forests (Johnson and Mayeux 1992).

Evidence from New Zealand and North America indicates that a result of 2 million years of climatic variation is many genetically variable plant species (Rattenbury 1962, Mitton and Jeffers 1989, Ogden 1989. Schoonmaker and Foster 1991). Some plant species include a wide range of climatic races (Bradshaw and McNeilly 1991). Genetically depauperate populations, by contrast, can be more susceptible to extinction (Ellstrand 1992). The effect of climate change may be accentuated with greater environmental variation (Cheplick 1991) such as in xeric and ecologically heterogeneous environments where genetic diversity generally increases (Nevo and Beiles 1989). Ogden (1989) has proposed the term "coenospecies" for species that have more or less frequently hybridized in the past and now possess a gene pool whose constitutent taxa have varied over time in both their ecological isolation and taxonomic distinction. Such inter-fertile species complexes can increase biodiversity (Wayne and Bazzaz 1991) and are observed in several woody genera today (Stebbins 1950, McArthur et al. 1988, Andersson 1990).

Hybridization appears to facilitate the ability of some plant species to adapt to (Rattenbury 1962, Ogden 1989, Andersson 1990) or evolve in response to (McArthur et al. 1988) changes in climate. For some species, hybridization may be the only source of adequate variation to survive changing environmental conditions (Bradshaw and McNeilly 1991). DNA analyses of Utah juniper in western Nevada indicate various levels of hybridization with western juniper ( $J$. occidentalis australis Hook) (authors' unpublished data). Hybridization is currently evident in the vicinity of the woodrat midden sites and may help explain how juniper was able to persist over most of 30,000 years of climate change.

Other genera in the southwestern U.S. also exhibit the itial for increased genetic variability from hybridization. An e...... ple is sagebrush (Artemisia spp.). Range contractions and expansions and associated hybridizations in response to changing climate are felt to have been important in its evolution (Shultz 1986, McArthur et al. 1988, Welch and McArthur 1990). Other examples include rabbitbrush (Chrysothamnus spp.) (Anderson 1986a, 1986b), and saltbush (Atriplex spp. L.) (Stutz 1978, 1984; Sanderson et al. 1990).

\section{Implications for Vegetation Dynamics}

Plant species present today in the Great Basin and around the world survived past climate changes by adapting, migrating, or both. Adaptability has limits, however, and is highly variable between species (Bradshaw and McNeilly 1991). Each species responds differently, usually indirectly (Bond and Richardson 1990), and on different time scales (Webb 1986, Huntley 1991) to changes in specific climatic variables. For most North American and European plant species, adaptation on site appears limited, and migration may be the principle means of coping with climate change (Turekian 1971, Iverson 1973, Bradshaw and McNeilly 1991).

Plant remains from ancient woodrat middens (Betancourt et al. 1990 ) and pollen from lakes, ponds, marshes, and dry caves (Bryant and Holloway 1985; Schoonmaker and Foster 1990, 1991) indicate that adaptation, as well as migration, played a role in the response of some plant species to climate change. Individualistic and highly variable plant responses (Huntley and Birks 1983; Wigand 1987; Ogden 1989; Webb 1987; Nowak 1991; Schoonmaker and Foster 1991) have resulted in variable community composition on a site over time (Huntley 1991; Jablonski 1991; Prentice et al. 1991). Alterations of competitive interactions, species composition, and community dynamics by changes in climate have 
continued to the present (Neilson 1986, 1987; Nowak 1991; Johnson and Mayeux 1992). Like climate, some past communities have no modern analogs (Webb 1987, Anderson et al. 1989, Huntley 1990, Thompson 1990, Jackson and Whitehead 1991, Nowak 1991, Schoonmaker and Foster 1991).

The ongoing plant adaptations to climate change may be facilitating (accommodating) the thresholds, multiple steady states, and multiple successional pathways widely observed for many plant communities. The ball and trough figures from Krebs (1985) as applied by Laycock (1991), Allen and Hoekstra (1992), and George et al. (1992) can be modified to diagrammatically model the complex changes in successional processes in response to climate change in a simplified form (Fig. 4). For all parts of Figure 4 the horizontal axis represents change from herbaceous annuals through

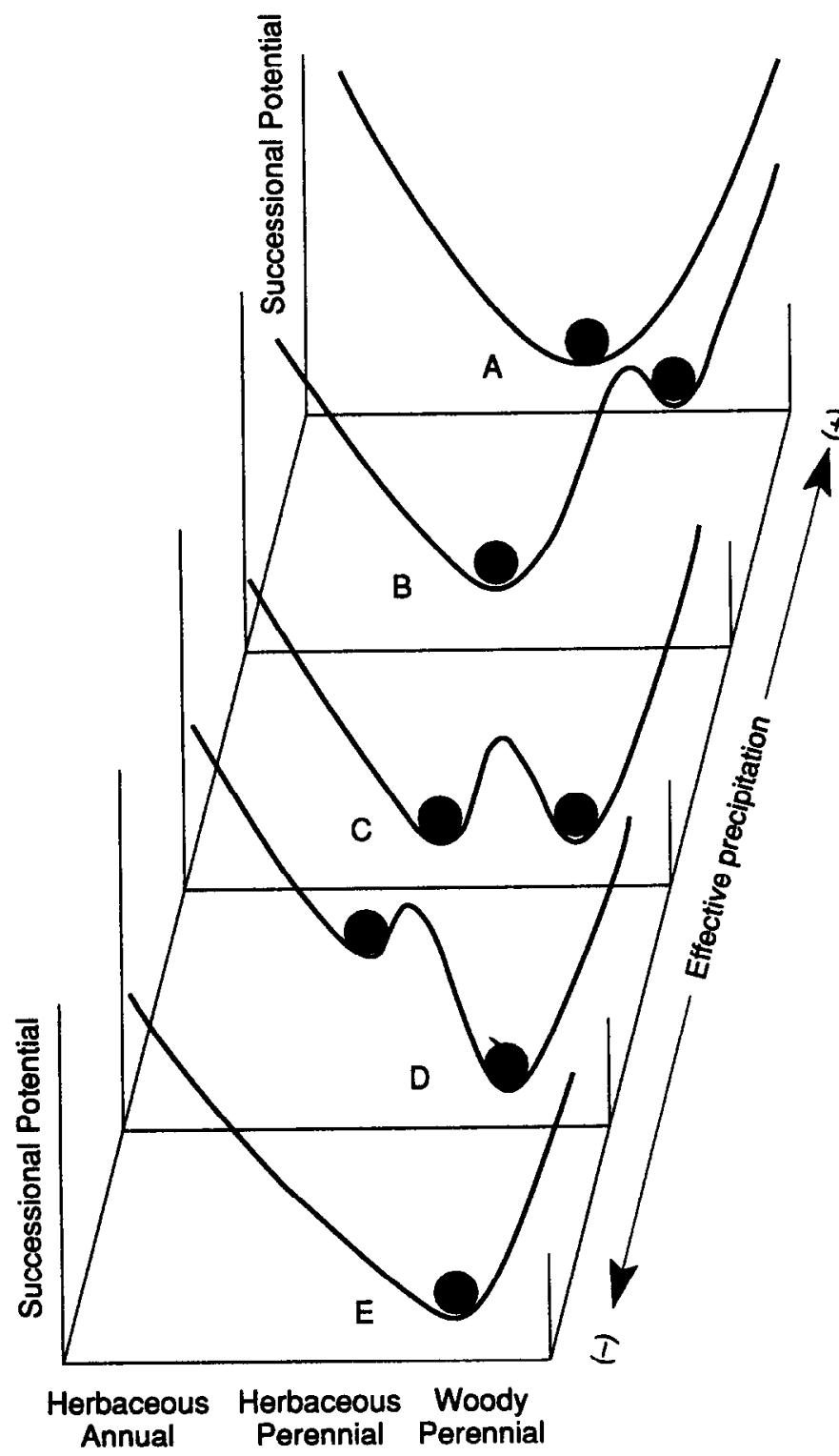

Fig. 4. A simplified ball and trough analogy of changing vegetation structure and specles composition with changing climate and changing community dynamics over long periods of time. Comparisons are for a situation with one herbaceous perennial and one woody perennial stable point. The community is represented by the ball and the surface variation represents the stable points, the threshold between them, and the surrounding potential for change over the range of species compositions for a given site, environment, and climatic condition for each point in time. Axes are relative. shrubs or trees for a hypothetical semiarid plant community in the American southwest. The intermediate position could be represented by perennial grass. The vertical axis represents a relative level of a potential for vegetation change along the gradient. Any disturbance of the stable state in Figure 4A, for example, activates the potential of the community to return to the stable point when the disturbance is removed. The patterns of return would be complex, nonlinear, and vary in rate and stability over time (Kay 1991), depending on the direction of change (Wissel 1984).

The long axis in Figure 4 represents effective precipitation, that useful for the biotic processes of plants. Effective precipitation increases to the upper right and decreases to the lower left. A change from upper right to lower left could result from either a shift in seasonality from spring/summer to more winter precipitation (Neilson 1986), a reduction in total precipitation, an increase in temperature, or a combination of changes. Variation in precipitation, and associated vegetation changes, can also indirectly interact with disease, insect infestation, or changes in fire intensity and frequency (Bond and Richardson 1990, Ryan 1991).

Variation among species in responses to decreasing effective precipitation can add a second woody perennial stable point with a threshold between it and the perennial grass stable point (Fig. 4B). Grazing may reduce herbaceous perennial dominance sufficiently to push the community across the threshold to dominance by woody perennials. In this instance a relatively low level of management effort may be sufficient to cause the vegetation to recross the threshold and return the community to perennial grass dominance. Following a fire at either stable point, the community may return temporarily to one dominated by herbaceous perennials.

An additional change in climate to even less effective precipitation could cause the situation in Figure $4 \mathrm{C}$. The woody perennial community is now more stable, with a threshold harder to recross to the original community. Under these conditions it may be possible for different communities to exist in equivalent environments, differing only in disturbance history. It may also be possible for the same disturbances to have different effects in different locations of the same community. Fire could move the community to the left along the $\mathrm{X}$-axis (Fig. 4C) followed by a return to perennial grass dominance. Grazing may move the community to the right across the threshold. Once the threshold is crossed vegetation dynamics following fire might change. Analogs of these processes are also present in the paleoecological record (Bond and Richardson 1990, Schoonmaker and Foster 1991).

Vegetation change may lag behind or be in disequilibrium with climate change for as much as 500 years from vegetation momentum or inertia (Fig. 4D) (Davis 1986, Webb 1986, Magnuson 1990) or even 1,000 years (Prentice et al. 1991). Even a grazing disturbance of limited intensity that reduced perennial grass dominance for Figure 4D could carry the community across the low threshold if the potential for change already existed because the climate had changed. Significant environmental changes would be required to reverse this situation. Fire, in contrast, might not result in the loss of perennial grass on the site as long as the dominant grass species were not reduced by direct damage. However, once the threshold to woody species dominance is cross the dynamics of fire might be changed. Figure 4D may describe the dynamics for many southwestern plant communities (Neilson 1986, Archer 1989) that were present when settlement began.

Further reductions in growing season precipitation could result in the loss of all potential for dominance by herbaceous perennials (Fig. 4E). This is typical of the woody plant dominance in many arid and semiarid communities possibly caused by a reduced fire frequency (Archer 1989) resulting from reduced fine fuels.

This model can also be modified to describe the effects of introducing a preadapted annual species, such as cheatgrass (Bromus 
tectorum L.) and other annuals into a perennial dominated community (George et al. 1992). Many ecosystems appear to be susceptible to such introductions (Johnson and Mayeux 1992) and they represent changes in the conditions on a site (Svejcar and Tausch 1991) that affect competitive interactions among species (Melgoza et al. 1990). More recent expansions in the ranges of introduced annuals may be encouraged by continuing changes in climate (Tausch et al. in press). Once present, these species appear to be creating new stable states and altering thresholds (Fig. 5)

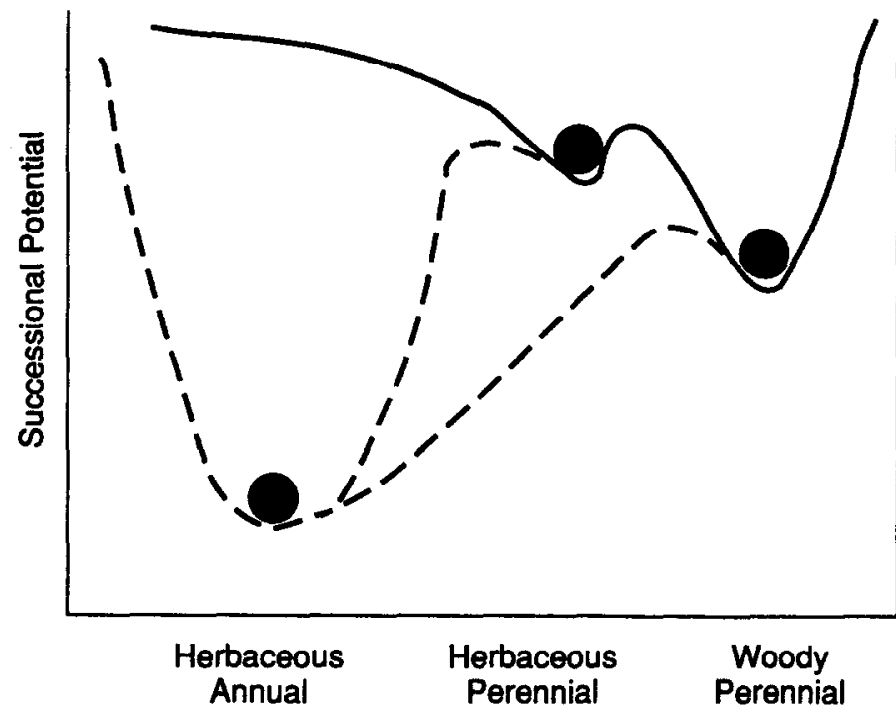

Fig. 5. A modificaton of Fig. 4D to incorporate the potential modification of thresholds, successional potential, and stable points by the introduction of an alien annual grass. The community is represented by the ball and the surface variation represents the stable points, the thresholds between them, and the surrounding potentials for change over the range of species compositions for a given site and environment. Axes are relative.

through both increased fire frequency (Whisenant 1990, Young and Tipton 1990) and altered competitive interactions (Tausch et al. in press). The height of thresholds between the new annual herbaceous stable point and the herbaceous perennial and woody perennial stable points (Fig. 5) may depend on disturbance and precipitation patterns. Annual dominace may or may not occur following fire, depending on site conditions and associates species composition. For example, fire encourages dominance by annuals in the more xeric but not necessarily in the more mesic areas of the sagebrush steppe.

Figures 4 and 5 represent a simplified series of changes in vegetation structure in response to changing environmental conditions. They are an abstraction of the ability of communities to persist over some range of disturbance, and then shift to and persist in some new structure when that range is exceeded. Along the gradient in effective precipitation the particular species or functional group dominating each stable state could vary with small-scale environmental and topographic differences between sites. Patterns and rates of change apparently can also vary around and between stable states. In a different location both perennial communities in Figure 4 could be woody dominated. An example is a douglas fir community existing under inertia and converted to ponderosa pine by logging or fire. Following fire, trajectories of vegetation change may differ in grazed and ungrazed subalpine forest (Baker 1991).

Figures 4 and 5 also only show a maximum of 2 to 4 stable states on 3 axes. In reality, more complex, nonlinear surfaces defined by several environmentally based axes, with an intricate interaction of several stable states and thresholds between them, are possible (Westoby et al. 1989a, 1989b; Laycock 1991; Friedel 1991). Many factors can be involved, with each likely to be important on different temporal and spatial scales (Pimm 1991).

Figures 4 and 5 can be used to illustrate many of the patterns of vegetation change observed over the last century (Neilson 1986, Archer 1989, Schlesinger et al. 1990). Where the balance between woody and herbaceous dominance was tenuous, such as perennial grass persisting by vegetation inertia (Fig. 4D), livestock may have been an additional factor affecting the rate more than the direction of change (Johnson and Mayeux 1992). Although grazing and changes in fire frequency may have played a part in the observed vegetation changes, simultaneous climate change associated with the end of the "Little Ice Age" also appears to have played a role (Neilson 1986, 1987). The need for a model based on climate change is thus supported by the rapidity, sometimes in only 2 to 3 decades, with which changes in southwestern vegetation occurred following settlement (Young et al. 1978, West 1983).

\section{Conclusions}

The ecosystem idea represents a paradigm (Higashi and Burns 1990) used to synthesize principles of ecological science into a set of concepts or models to interpret the highly complex, nonlinear causal networks or developmental pathways of energy, matter, and information flows (Burns 1990, Kay 1991). These models of ecosystem dynamics have been largely based on assumptions of equilibrium conditions (Schoonmaker and Foster 1991). Equilibrium conditions, however, are an artifact of the temporal and spatial scales of the observations of which they are based (DeAngelis and Waterhouse 1987). From the approximately 100,000 to 1.6 million years of available vegetation change data, it is apparent that today's communities are composed of species that arrived at different times, from different sources, and that had to cope with different biotic interactions (Ogden 1989, Huntley 1991, Schoonmaker and Foster 1991). Past vegetation changes generally coincide with climate variations that records of temperature (Eddy and Bradley 1991) and lake level fluctuations (Smiley et al. 1991) indicate have been occurring for about 2 million years. Each combination of species, environment, and topography is in some way unique in both space and time. There is no "natural vegetation" in the common usage or interpretation of the term based on equilibrium conditions. Many ecological principles and concepts, and the ecosystem paradigms derived from them will need revision to incorporate the past, present, and future spatial and temporal variation.

Today, no area is without some level of human impact (West 1993). Future communities can never be exactly what they were (Box 1992). Our current knowledge is still insufficient to fully grasp, much less predict, the interactions between future climate change and terrestrial ecosystems (Mooney 1991). Overall, the history of climate change; our land use impacts; our alteration of atmospheric chemistry and the potential effects of such alteration on current plant growth (Bazzaz and Garbut 1988) and future climate; the introduction of exotic species; and other human alteration of environmental conditions make present and future conditions unique and the long-term consequences unknown.

Because every community is influenced by many spatial and temporal factors, nonmanagement is impossible. A hands-off approach is also management, and will usually result in community dynamics that are new and possibly undesirable (Box 1992, Diamond 1992, West 1993). Management principles need revision to address nonequilibrium theories (Johnson and Mayeux 1992). This will involve an ongoing interaction with nature (Botkin 1990) through continuous management and monitoring of the direction and rates of vegetation change (West 1991).

Concepts that need changing based on the patterns of the past include that of habitat type and potential natural community. Changes in environmental conditions can potentially change dom- 
inance patterns and species composition, effectively changing the habitat type or potential natural community. Present condition and trend methods are based on the concept of a single end-point community with a specific species composition. Such efforts to identify only one hypothetical community as the potential for a site are no longer justifiable. In reality we can have a number of communites to choose from, many of which are structurally and functionally similar despite differences in species composition (Johnson and Mayeux 1992). Wherever multiple possibilities occur, they and their conditions of existence need to be recognized and understood.

Because more than one stable point exists, we need to consider what the best desired community might be from within the site capabilities and its potential uses. An important part of the decision will be to base management on the sustainment of ecosystem function, which can probably be achieved by various combinations of species (Johnson and Mayeux 1992). Knowledge of past climate changes of at least the late Quaternary, and associated changes in environmental conditions and species composition, can be as important as knowledge of the present for understanding plant community dynamics and their implications for management. Extrapolation of this knowledge for prediction of future functional assemblages will be one of our most difficult tasks (Mooney 1991).

\section{Literature Cited}

Adam, D.P. 1985. Quaternary pollen records from California, p. 125-140. In: V.M. Bryant, Jr., and R.G. Holloway (eds.), Pollen records of late-Quaternary North American sediments. Amer. Assoc. Stratigraphic Palynologists, Dallas, Tex.

Adam, D.P. 1988. Palynology of two upper Quaternary cores from Clear Lake, Lake County, California. U.S. Geol. Survey Professional Paper 1363.

Allen, T.H.F., and T.W. Hoekstra. 1992. Toward a unified ecology. Columbia Univ. Press, N.Y.

Anderson, L.C. 1986a. Cytogeography of Chrysothamnus viscidiflorus, p. 93-97. In: E.D. McArthur and B.L. Welch (eds.), Proc. Symp. The Biology of Artemisia and Chrysothamnus. USDA Forest Serv. Intermountain. Res. Sta. Gen. Tech. Rep. INT-200. Ogden, Utah.

Anderson, L.C. 1986b. Sympatric subspecies in Chrysothamnus nauseosus, p. 98-103. In: E.D. McArthur and B.L. Welch (eds.), Proc. Symp. The biology of Artemisia and Chrysothamnus. USDA Forest Serv. Intermountain Res. Sta. Gen. Tech. Rep. INT-200. Ogden, Utah.

Anderson, P.M., P.J. Bartlein, L.B. Brubaker, K. Gajeuski, and J.C. Ritchie. 1989. Modern analogues of late Quaternary pollen spectra from the western interior of North America. J. Biogeography 16:573-596.

Andersson, L. 1990. The driving force: Species concepts and ecology. Taxon 39:375-382.

Archer, S. 1989. Have southern Texas savannahs been converted to woodlands in recent history? Amer. Natur, 134:545-561.

Archer, S., and F.E. Smeins. 1992. Non-linear dynamics in grazed ecosystems: Thresholds multiple steady states and positive feedbacks, p. 4-6. In: Is the Range Condition Concept Compatible with Ecosystem Dynamics? Proc. Symp. 1992 Annual Meeting Soc. Range Manage., Spokane, Wash.

Baker, W.L. 1991. Livestock grazing alters succession after fire in a Colorado subalpine forest, p. 84-90. In: S.C. Nodvin and T.A. Waldrop (eds.), Fire and environment: Ecological and cultural perspectives. USDA Forest Serv. Gen Tech. Rep. SE-69. Asheville, N.C.

Barbour, M.G., and W.D. Billings (eds.). 1988. North American terrestrial vegetation. Cambridge Univ. Press, Cambridge, UK.

Bazzax, F.A., and K. Garbut. 1988. The response of annuals in competitive neighborhoods: effects of elevated $\mathrm{CO}_{2}$. Ecology 69:937-946.

Bennett, K.D. 1990. Milankovich cycles and their effects on species in ecological and evolutionary time. Paleobiology 16:11-21.

Benson, L.V. 1991. Timing of the last highstand of Lake Lahontan. J. Paleolimnology 5:115-126.

Benson, L.V., and R.S. Thompson. 1987. Lake-level variation in the Lahontan Basin for the past 50,000 years. Quat. Res. 28:69-85.

Benson, L.V., D.R. Currey, R.I. Dorn, K.R. Lajoie, C.G. Oviatt, S.W. Robinson, G.I. Smith, and S. Stine. 1990. Chronology of expansion and contraction of four Great Basin lake systems during the past 35,000 years. Paleogeography, Paleoclimatology, Paleoecology 78:241-286.
Berglund, B.E. (ed.) 1986. Handbook of Holocene Paleoecology and Paleohydrology. John Wiley and Sons, N.Y.

Betancourt, J.L., T.R. VanDevender, and P.S. Martin. 1990. Packrat middens: The last $\mathbf{4 0 , 0 0 0}$ years of biotic change. Univ. of Arizona Press, Tucson.

Bond, W.J., and D.M. Richardson. 1990. What can we learn from extinctions and invasions about the effects of climate change? S. African J. Sci. 86:429-433.

Botkin, D.B. 1990. Discordant harmonies. Oxford Univ. Press. N.Y.

Box, T.W. 1992. Rangelands, desertification, and Clements' ghost, a viewpoint paper. Rangelands 14:329-331

Bradshaw, A.D., and T. MeNeilly. 1991. Evolutionary response to global climate change. Ann. Bot. 67:5-14.

Brice, W.C. 1978. The environmental history of the Near and Middle East since the last ice age. Academic Press, N.Y.

Bryant, V.M. Jr., and R.G. Holloway (eds.) 1985. Pollen records of late Quaternary North American Sediments. Amer. Assoc. Stratigraphic Palynologists, Dallas, Tex.

Burkhardt, J.W., and E.W. Tisdale. 1976. Causes of juniper invasion in southwestern Idaho. Ecology 57:472-484

Burns, T.P. 1990. The power of the ecosystem concept and paradigm. Physiol. Ecol. Japan 27:191-197.

Cheplick, G.P. 1991. A conceptual framework for the analysis of phenotypic plasticity and genetic constraints in plants. Oikos 62:283-291.

Davis, J.O., R. Elston, and G. Townsend. 1976. Coastal geomorphology of the south shore of Lake Tahoe: suggestion of an altithermal lowstand. Holocene environmental change in the Great Basin. Nevada Archaeological Survey Res. Paper 6. Reno, Nev.

Davis, M.B. 1986. Climatic instability, time lags, and community disequilibrium, p. 269-284. In: J. Diamond and T.J. Case (eds.). Community ecology. Harper and Row, N.Y.

DeAngelis, D.L., and J.C. Waterhouse. 1987. Equilibrium and nonequilibrium concepts in ecological models. Ecol. Monogr. 57:1-21.

Diamond, J. 1992. Must we shoot deer to save nature? Natural History, Aug. 1992, p. 2-8.

Eddy, J.A., and R.S. Bradley. 1991. Science capsule, University Corporation for Atmospheric Research, Office of Interdisciplinary Earth Studies. EarthQuest 5(1):supplement.

Ellstrand, N.C. 1992. Gene flow by pollen: implications for plant conservation genetics. Oikos 63:77-86.

Foster, D.R., P.K. Schoonmaker, and S.T.A. Pickett. 1990. Insights from paleoecology to community ecology. Trends Ecol. Evol. 5:119-122.

Friedel, M.H. 1991. Range condition assessment and the concept of thresholds: A viewpoint. J. Range Manage. 44:422-426.

Furgurson, E.B., and G.F. Mobley. 1992. Lake Tahoe: Playing for high stakes. Nat. Geog. 181:112-132.

Geist, V. 1989. Did large predators keep humans out of North America? p. 282-293. In: J. Clutton-Brock (ed.), The walking larder: Patterns of domestication, pastoralism, and predation. Unwin Hyman, London.

George, M.R., J.R. Brown, and W.J. Clawson. 1992. Application for nonequilibrium ecology to management of Mediterranean grasslands. $J$. Range Manage. 45:436-440.

Gould, S.J. 1991. Abolish the recent. Natur. Hist., May 1991. p. 16-21.

Grayson, D.K. 1991. Late Pleistocene mammalian extinction in North America: taxonomy, chronology and explanations. J. World Prehistory 5:193-232.

Heusser, C.J. 1985. Quaternary pollen records from the Pacific Northwest coast: Aleutions to the Oregon-California boundary, p. 141-165. In: V.M. Bryant, Jr. and R.C. Holloway (eds.), Pollen records of Late Quaternary North American sediments. Amer. Assoc. Stratigraphic Palynologists. Dallas, Tex.

Heusser, L.E., and J.E. King. 1988. North America: With special emphasis on the development of the Pacific Coastal forest and prairie/forest boundary prior to the last glacial maximum, p. 193-236. In: B. Huntley, and T. Webb III (eds.), Vegetation history. Kluwer Acad. Publ., Dordrecht, Netherlands.

Higashi, M., and T.P. Burns. 1990. Enrichment of ecosystem theory, p. 1-38. In: M. Higushi and T.P. Burns (eds.), Theoretical studies of ecosystems: The network perspective. Cambridge Univ. Press, Cambridge, UK.

Huntley, B. 1990. Dissimilarity mapping between fossil and contemporary pollen spectra in Europe for the past 13,000 years. Quat. Res. 33:360-376.

Huntley, B. 1991. How plants respond to climate change: Migration rates, individualism and the consequences for plant communities. Ann. Bot. 67:15-22. 
Huntley, B., and J.B. Birks. 1983. An atlas of past and present pollen maps for Europe: 0-13,000 years ago. Cambridge Univ. Press, Cambridge, UK.

Huntley, B., and T. Webb III. 1989. Migration: Species' response to climatic variations caused by changes in the earth's orbit. J. Biogeogr. 16:5-19.

Iverson, J. 1973. The development of Denmark's nature since the last glacial. Denmarks Geologiske Underspgelse V. Raekke. NR. 7-C. C.A Reitzels Forlog. Copenhagen, Denmark.

Jablonski, D. 1991. Extinctions: A paleontological perspective. Sci. 253:754-757.

Jackson, S.T., and D.R. Whitehead. 1991. Holocene vegetation patterns in the Adirondack Mountains. Ecology 72:641-653.

Jacobson, G.L. T. Webb, and E.C. Grimm. 1987. Patterns and rates of vegetation change during the deglaciation of eastern North America, $p$. 277-288. In: W.F. Ruddiman and H.E. Wright (eds.), The geology of North America. Vol. K-3. Geological Soc. Amer., Boulder, Colo.

Johnson, H.B., and H.S. Mayeux. 1992. Viewpoint: A view on species additions and deletions and the balance of nature. J. Range Manage. 45:322-333

Jorgenson, S.E. 1990. Ecosystem theory, ecological buffer capacity, uncertainty and complexity. Ecol. Modeling. 52:125-133.

Kay, J.J. 1991. A nonequilibrium thermodynamic framework for discussing ecosystem theory. Environ. Manage. 15:483-495.

Krebs, C.J. 1985. Ecology: The experimental analysis of distribution and abundance, 3rd ed. Harper and Row, N.Y

Kurten, B., and E. Anderson. 1980. Pleistocene mammals of North America. Columbia Univ. Press, N.Y.

Laycock, W.A. 1991. Stable states and thresholds of range condition on North American rangelands: A viewpoint. J. Range Manage. 44:427-433.

Lewin, R. 1987. Domino effect invoked in ice age extinctions. Science 238:1509-1510.

Lindstrom, S. 1990. Submerged tree stumps as indicators of mid-Holocene aridity in the Lake Tahoe Basin. J. Calif. Great Basin Anthropol. 12:146-157.

Magnuson, J.J. 1990. Long-term ecological research and the invisible present. Bioscience 40:495-501.

McArthur, E.D. B.L. Welch, and S.C. Sanderson. 1988. Natural and artificial hybridization between big sagebrush (Artemisia tridentata) subspecies. J. Heredity 79:268-276.

Melgoza, G., R.S. Nowak, and R.J. Tausch. 1990. Soil water exploitation after fire: Competition between Bromus tectorum (cheatgrass) and two native species. Oecologia 83:7-13.

Mitchell, J.M. 1976. An overview of climatic variability and its causal mechanisms. Quat. Res. 6:481-493.

Mitton, J.B., and R.M. Jeffers. 1989. The genetic consequences of mass selection for growth rate in Englemann spruce. Silvae Genetica 38:6-12.

Mooney, H.A. 1991. Biological response to climate change: An agenda for research. Ecol. App. 1:112-117.

Morrison, R.B. 1991a. Introduction, p. 1-12. In: R.B. Morrison (ed.), Quaternary Nonglacial Geology: Conterminous U.S. Geological Soc Amer., Boulder, Colo.

Morrison, R.B. 1991b. Quaternary stratigraphic, hydrologic, and climatic history of the Great Basin, with emphasis on Lakes Lahontan, Bonneville, and Tecopa, p. 283-320. In: R.B. Morrison (ed.), Quaternary nonglacial geology: Conterminous U.S. Geological Soc. Amer., Boulder, Colo.

Neilson, R.P. 1986. High-resolution climatic analysis and southwest biogeography. Science 232:27-34

Neilson, R.P. 1987. Biotic regionalization and climatic controls in western North America. Vegetatio 70:135-147.

Nevo, E., and A. Beiles. 1989. Genetic diversity in the desert: Patterns and testable hypotheses. J. Arid Environ. 17:241-244.

Nilsson, T. 1982. The Pleistocene. D. Reidel Publ, Dordrecht, Holland.

Nowak, C.L. 1991. Reconstruction of post-glacial vegetation and climate history in western Nevada: Evidence from plant macrofossils in Neotoma middens. M.S. Thesis, Univ. Nevada, Reno.

Ogden, J. 1989. On the coenospecies concept and tree migrations during the oscillations of the Pleistocene climate. J. Royal Soc. New Zealand 19:249-262.

Owen-Smith, N. 1987. Pleistocene extinctions: The pivotal role of megaherbivores. Paleobiology 13:351.

Pimm, S.L. 1991. Balance of nature? Univ. Chicago Press, Chicago, Ill.

Prentice, I.C., P.J. Bartleim, and T. Webb, IIl. 1991. Vegetation and climate change in eastern North America since the last glacial maximum. Ecology 72:2038-2056
Rattenbury, J.A. 1962. Cyclic hybridization as a survival mechanism in the New Zealand forest flora. Evolution 16:348-363.

Ryan, K.C. 1991. Vegetation and wildland fire: Implications of global climate change. Environ. Int. 17:169-178.

Sanderson, S.C., H.C. Stutz, and E.D. MCArthur. 1990. Geographic differentiation in Atriplex confertifolia. Amer. J. Bot. 77:490-498.

Savage, M. 1991. Structural dynamics of a southwestern pine forest under chronic human influence. Ann. Assoc. Amer. Geo. 81:271-289.

Schlesinger, W.G., J.F. Reynolds, G.L. Cunningham, L.F. Huenneke, W.W. Jarell, R.A. Virginia, and W.G. Whitford. 1990. Biological feedbacks in global desertification. Science 247:1043-1048.

Scholes, D.J. 1990. Change in nature and the nature of change: Interactions between terrestrial ecosystems and the atmosphere. S. African J. Sci. 86:350-354.

Schoonmaker, P.K., and D.R. Foster. 1989. Stand-level forest history in central New England investigated by pollen analysis. Bull. Ecol. Soc. Amer. 70:256

Schoonmaker, P.K., and D.R. Foster. 1990. Long-term forest history from pollen in soils and hollows versus stem reconstruction: A comparison of techniques and results. Bull. Ecol. Soc. Amer. 71:317

Schoonmaker, P.K., and D.R. Foster. 1991. Some implications of paleoecology for contemporary ecology. Bot. Rev. 57:204-244.

Shultz, L.M. 1986. Taxonomic and geographic limits of Artemisia subgenus Tridentatae (Beetle) McArthur (Asteraceae; Anthemidae), p. 20-28. In: E.D. McArthur and B.L. Welch (eds.), Proc. Symp. The Biology of Artemisia and Chrysothamnus. USDA Forest Serv., Intermountain Res. Sta. Gen. Tech. Rep. INT-200. Ogden, Utah.

Smiley, T.H., R.A. Bryson, J.E. King, G.J. Kukla, and G.I. Smith. 1991. Quaternary paleoclimates, p. 13-44. In: R.B. Morrison (ed.), Quaternary nonglacial geology: Conterminous U.S. Geol. Soc. Amer. Boulder, Colo.

Sprugel, D.G. 1991. Disturbance, equilibrium, and environmental variability: What is 'natural' vegetation in a changing environment? Biol. Cons. 58:1-18.

Stebbins, G.L., Jr. 1950. Variation and evolution in plants. Columbia Univ. Press, N.Y.

Stutz, H.C. 1978. Explosive evolution of perennial Atriplex in western North America. Great Basin Natur. Memior. 2:161-168.

Stutz, H.C. 1984. A tour of chenopods in western Utah, p. 2-11. In: A.R. Tiedmann, E.D. McArthur, H.C. Stutz, R. Stevens, and K.L. Johnson (eds.), Proc. Symp. Biology of Atriplex and Related Chenopods. USDA Forest Serv., Intermountain Res. Sta. Gen. Tech. Rep. INT-172. Ogden, Utah.

Svejear, T., and J.R. Brown. 1991. Failures in the assumptions of the condition and trend concept for management of natural ecosystems. Rangelands 13:165-167.

Svejcar, T., and R.J. Tausch. 1991. Anaho Island, Nevada: A relic area dominated by annual invader species. Rangelands 13:233-236.

Tausch, R.J., T. Svejcar, and J.W. Burkhardt. (in press). Patterns of annual grass dominance on Anaho Island: Implications for Great Basin vegetation management. In: S.B. Monson (ed.), Symp. Ecology, Management, and Restoration of Intermountain Annual Rangelands, USDA Forest Serv., Gen. Tech. Rep. Ogden, Utah.

Thompson, R.S. 1990. Late Quaternary vegetation and climate in the Great Basin, p. 200-239. In: J.L. Betancourt, T.R. Van Devender, and P.S. Martin (eds.), Fossil packrat middens: The last 40,000 years of biotic change. Univ, Arizona Press, Tucson.

Thompson, R.S. 1991. Pliocene environments and climates in the western United States. Quat. Sci. Rev. 10:115-132.

Thompson, R.S., L. Benson, and E.M. Hattori. 1986. A revised technology for the last Pleistocene lake cycle in the central Lahontan Basin. Quat. Res. 25:10-10.

Turekian, K.K. (ed.). 1971. The late Cenozoic glacial ages. Yale Univ. Press, New Haven, Conn.

van Donk, J. 1976. $0^{18}$ of the Atlantic Ocean for the entire Pleistocene Epoch Memior. Geol. Soc. Amer. 145:147-164.

Wahl, E.W., and T.L. Lawson. 1970. The climate of the mid-nineteenth century United States compared to the current normals. Monthly Weather Rev, 98:259-265

Walker, D.A. 1982. Vegetation's fourth dimension. New Phytol. 90:419-429.

Wayne, P.M., and F.A. Bazzaz. 1991. Assessing diversity in plant communities: The importance of within species variation. Trends Ecol. Evol. $6: 400-404$

Webb, T., III. 1986. Is vegetation in equilibrium with climate? How to interpret the late-Quaternary pollen data. Vegetatio 67:75-91. 
Webb, T., III. 1987. The appearance and disappearance of major vegetational assemblages: Long term vegetational dynamics in eastern North America. Vegetatio 69:177-187.

Webb, T., III. 1991. The spectrum of temporal climatic variability: Current estimates and the need for global and regional time series, p. 61-81. In: R.S. Bradely (ed.), Global changes and the past. Univ. Corp. for Atmos. Res., Office of Interdisciplinary Earth Studies, Boulder, Colo.

Webb, R.H., and J.L. Betancourt. 1990. The spatial and temporal distribution of radiocarbon ages from packrat middens, p. 85-102. In: J.L. Betancourt, T.R. VanDevender, and P.S. Martin (eds.), Packrat middens: The last 40,000 years of biotic change. Univ. Arizona Press, Tucson.

Welch, B.L., and E.D. McArthur. 1990. Keynote address: Big sagebrushits taxonomy, origin, distribution and utility, p. 3-18. In: H.G. Fisser (ed.), Proc. 14th Wyoming Shrub Ecology Workshop. May 1985, Univ. Wyoming, Laramie.

West, N.E. 1983. Great Basin-Colorado Plateau sagebrush semi-desert, p. 331-349. In: N.E. West (ed.), Temperate deserts and semi-deserts. Elsevier Sci. Pub., Co., N.Y.

West, N.E. 1991. Benchmarks for rangeland management and environmental qualty, p. 31-44. In: L.F. James, J.O. Evans, M.H. Ralphs, and R.D. Child (eds.), Noxious range weeds, Westview Press, Boulder, Colo.

West, N.E. 1993. Biodiversity on rangelands. J. Range Manage. 46:2-13.

Westoby, M., B. Walker, and I. Noy-Meir. 1989a. Opportunistic management for rangelands not at equilibrium. J. Range Manage. 42:266-274.

Westoby, M., B. Walker, and I. Noy-Meir. 1989b. Range management on the basics of a model which does not seek to establish equilibrium. J. Arid. Environ. 17:235-239.
Whisenant, S.G. 1990. Changing fire frequencies on Idaho's Snake River Plains: Ecological and management implications, p. 4-10. In: E.D. McArthur, E.M. Romney, S.D. Smith, and P.T. Tueller (eds.), Proc. Symp. Cheatgrass Invasion, Shrub Dieoff, and Other Aspects of Shrub Biology and Management. USDA Forest Serv., Intermountain Res. Sta. Gen. Tech. Rep. INT-276, Ogden, Utah.

Wigand, P.E. 1987. Diamond Pond, Harney County, Oregon: Vegetation history and water table in the eastern Oregon desert. Great Basin Natur. 47:427-458.

Wigand, P.E., and C.L. Nowak. 1992. Dynamics of Northwestern Nevera plant communities during the last 30,000 years, p. 40-62. In: C.A. Hull, Jr., V. Doyle-Jones, and B. Widawski (eds.), The history of water: Eastern Sierra Nevada, Owens Valley, White-Inyo Mountains, Vol. IV. White Mountain Res. Sta. Symp. Univ. of California Press, Berkeley.

Wissel, C. 1984. A universal law of the characteristics return time near thresholds. Oecologia 65:101-107.

Winograd, I.J., T.B. Coplen, J.M. Landwehr, A.C. Riggs, K.R. Ludwig, B.J. Szabo, P.T. Kolesar, and K.M. Revesz. 1992. Continuous 500,000 year climate record from vein calcite in Devils Hole, Nevada. Science 258:255-260.

Young, J.A., R.E. Eckert, Jr., and R.A. Evans. 1978. Historical perspectives regarding the sagebrush ecosystem, p. 1-13. In: The Sagebrush Ecosystem: A Symposium. Utah State Univ., College Natur. Resour., Logan.

Young, J.A., and F. Tipton. 1990. Invasion of cheatgrass into arid environments of the Lahontan Basin., p. 37-40. In: E.D. McArthur, E.M. Rommey, S.D. Smith, and P.T. Tueller (eds.), Proc. Symp. Cheatgrass invasion, shrub dieoff and other aspects of shrub biology and management. USDA Forest Serv., Intermountain Res. Sta. Gen. Tech. Rep. INT-276. Ogden, Utah. 